\title{
Etiología viral de la diarrea infantil
}

\author{
Dres. elba wu H. *, carmen grado D. *, Fidel aVendaño C. * y german corey c. **
}

El problema de la morbimortalidad de la diarrea infantil ha sido por largo tiempo una situación no superada en Chile. Entre 1969 y $1971 \mathrm{apa}^{-}$ rece responsable de un $17 \%$ de la tasa de mortalidad infantil. En 1971, de 3.902 defunciones por sindrome diarreico, 3.243 ocurrieron en menores de un año ${ }^{1}$. Cabe destacar que en más o menos el $50 \%$ de los casos su etiología es desconocida ${ }^{2}$. Dentro de los agentes infecciosos, los virus causan parte de las diarreas infantiles, siendo los patógenos más importantes algunos tipos de virus ECHO, virus Coxsackie A y Adenovirus ${ }^{3}$, ${ }^{4}, 5$. Trabajos realizados en este laboratorio han mostrado que el virus ECHO 20 jugaría un papel etiológico en las diarreas del lactante ${ }^{6}$.

Se han encontrado diversos virus con capacidad patogénica, cuya participación específica en episodios de diarrea cambia aparentemente con el tiempo y lugar geográfico. Por ello, dada la magnitud del impacto de esta enfermedad, hemos continuado esta línea de investigación, estudiando la prevalencia de virus en el tubo digestıvo de] lactante y del preescolar chileno en el verano de 1973. En este trabajo presentamos los resultados de aislamiento de virus de las deposiciones y su posible poder patogénico.

Materiales y métodos. Se estudiaron 178 niños, entre un mes y seis años de edad, distribuidos en tres grupos. El grupo A está formado por 88 niños con diarrea aguda; prácticamente el $100 \%$ tenía una evolución de menos de 72 horas, y sólo 3 casos presentaban deshidratación. El grupo $\mathrm{B}$, por 50 niños controles sanos que no había tenido diarrea, ni enfermedades infecciosas en los 15 días previos a la toma de las muestras. El grupo C está formado por 40 niños sanos, contac-

\footnotetext{
* Unidad de Virología, Departamento de Microbiología y Parasitologia, Facultad de Medicina, Universidad de Chile. * Becado en Epidemiología, Servicio Nacional de Salud.
}

tos de los enfermos del grupo A. Los grupos A y B eran comparables en edad, procedencia, estado nutritivo y condiciones generales. La toma de las muestras se efectuó en los siguientes cons!iltorios periféricos de Santiago: a) "La Pincoya", con un total de 34 niños, desde el 2 al 12 de enero; b) Consultorio No 1, 56 niños, desde el 15 de enero al 9 de febrero; c) "San Joaquín", 9 niños, desde el 6 al 19 de febrero y d) "Bellavista", 79 niños, desde el 19 de febrero al 20 de marzo. Los servicios donde se recolectaron las muestras atienden, en general, a niños de escasos recursos socioeconómicos. A todos los niños se les hizo un estudio clínice-epidemiológico.

En la Tabla 1 se muestra la distribución por edad de los niños con diarrea y controles sanos. Se puede comprobar que ambos grupos son similares. No se incluye el grupo "contacto de los enfermos", ya que del total de 40 niños, 35 son mayores de dos años. La mayoría de los niños

\section{T A B L A 1}

DISTRIBUCION POR EDAD DE NIÑOS CON DIARREA (A) Y CONTROLES SANOS (B)

\begin{tabular}{|c|c|c|c|c|}
\hline \multirow[b]{2}{*}{ Edad } & \multicolumn{2}{|c|}{$\begin{array}{c}\text { Grupo A } \\
\text { "Diarrea" }\end{array}$} & \multicolumn{2}{|l|}{$\begin{array}{c}\text { Grupo B } \\
\text { "Sanos" }\end{array}$} \\
\hline & $N^{o}$ casos & $\%$ & $N^{o}$ casos & $\%$ \\
\hline 6 meses o menos & 30 & 34,0 & 16 & 32,0 \\
\hline 6 meses 1 día - 1 año & 20 & 22,7 & 10 & 20,0 \\
\hline 1 año 1 día -2 años & 23 & 26,2 & 14 & 28,0 \\
\hline 2 años 1 día -3 años & 9 & 10,3 & 5 & 10,0 \\
\hline 3 años 1 día -4 años & 1 & 1,1 & 2 & 4,0 \\
\hline 4 años 1 día -5 años & 2 & 2,3 & 1 & 2,0 \\
\hline 5 años 1 día - 6 años & 3 & 3,4 & 2 & 4,0 \\
\hline Total & 88 & 100,0 & 50 & 100,0 \\
\hline
\end{tabular}


con diarrea son menores de dos años $(82,9 \%)$ y más de la mitad son menores de un año $(56,7 \%)$.

Para el estudio virológico se tomó dos muestras de deposiciones con un intervalo de 4 a 7 días, mediante tórula rectal. Además, se recolectó dos muestras de sangre de los niños con diarrea, con un lapso de 15 a 20 días (fase aguda y convalecencia). La técnica de recolección, traslado, preparación y conservación de las muestras ya ha sido descrita ${ }^{6}$. Las muestras se inocularon en duplicado, en líneas celulares (HEp 2 y LLC) y en cultivo primario de células de amnios humano, observándose los tubos inoculados durante 10 a 14 días. Aquéllos que mostraron algún efecto citopático fueron traspasados 3 a 4 veces para descartar efectos inespecíficos y/o aumentar la concentración viral. Se inocularon 120 muestras, representativas del total, en ratones recién nacidos, vía subcutánea, los que se observaron durante 10 días. Se sacrificaron aquellos con enfermedad típica o sospechosa de virus Coxsackie, preparándose un homogenizado de su tejido muscular. Este se reinoculó tanto en ratones como en células HEp 2 para determinar el grupo de virus Coxsackie.

La clasificación antigénica de los virus aislados se realizó utilizando la técnica de neutralización ${ }^{7}$ con sueros tipos *. Sólo se tipificó enterovirus; usando $100 \mathrm{DCT}_{50}$ de virus se neutralizó primero contra los tres tipos de sueros antipolio en forma separada. Las muestras no neutralizadas por estos sueros fueron ensayadas con mezclas de anticuerpos para virus ECHO (todos los tipos) y Coxsackie B (los seis tipos), siguiendo la técnica de Lim y Benyesh-Melnick ${ }^{8}$. Los virus no clasificados por este método fueron expuestos primero a una mezcla de sueros antipolio, luego a una de sueros ECHO y Coxsackie B; de esta manera se puede evidenciar la existencia simultánea de un viruspolio con otro enterovirus. Aquéllos que no fueron neutralizados por estos anticuerpos y que dieron un efecto citopático diferente al de los virus herpes y adenovirus se han denominado virus "no tipificable". Los virus aislados en ratones recién nacidos, considerados del grupo Coxsackie A por las características de las manifestaciones paralíticas y por no producir efecto citopático al ser traspasados a células HEp 2, no fueron tipificados por razones de economía del vivero.

La titulación de anticuerpos neutralizantes específicos se hizo simultáneamente en los sueros de fase aguda y convalescencia, diluidos de $4: 4$, ya sea frente a 100 DCT $_{50}$ del virus aislado, cuando éste no fue tipificable, o frente a $100 \mathrm{DCT}_{50}$ del virus tipo identificado previamente. La mezcla suero-virus se probó en células primarias de amnios humano cuando el virus clasificado era

\footnotetext{
* Los sueros tipos fueron gentilmente proporcionados por el National Institute of Health de EE.UU. de N.A.
}

ECHO; en la línea celular HEp 2 cuando se trataba de viruspolio o Coxsackie $\mathrm{B}$, y en el mismo tipo de cultivo al utilizado originalmente cuando el virus era "no tipificable". No se hizo determinación de anticuerpos neutralizantes contra virus Coxsackie A ni virus herpes.

Resultados. Como una contribución al estudio de la etiología de las diarreas se presenta la Tabla 2 en la que se muestra la prevalencia de agentes infecciosos --virus, bacterias y parásitosencontrados en las deposiciones de los 3 grupos de niños. En un $43 \%$ de los niños con diarrea no se detecta ningún agente infeccioso. El porcentaje de los niños con diarrea que tienen virus en sus deposiciones, como único agente infeccioso, es mayor que el observado en los niños sanos y en los contactos. Los otros niños con diarrea que tienen virus en sus coprocultivos presentan una infección mixta-virus-bacteria, virus-parásito o virus-bacteria-parásito y representan 10 de los 16 casos que tienen mezcla de agentes infecciosos. Los seis casos restantes tienen bacterias y parásitos. En los niños controles se encuentra que un $54 \%$ no tiene agentes infecciosos en sus deposiciones; este porcentaje es menor en los niños contacto $(20 \%)$, grupo que presenta un elevado índice de enteroparasitosis $(45 \%)$.

La prevalencia de virus en las diferentes edades se analizan en la Tabla 3 . El aislamiento viral de las deposiciones en el total de los niños es porcentualmente similar en los tres grupos analizados, encontrándose más virus en las deposiciones de los niños con diarrea y sus contactos que

T A B L A 2

AGENTES INFECCIOSOS AISLADOS DE DEPOSICIONES

NIÑOS CON DIARREA (A), CONTROLES SANOS

(B) Y CONTACTOS DE DIARREA (C)

\begin{tabular}{|c|c|c|c|c|c|c|}
\hline & $\begin{array}{r}\text { Grup } \\
\text { “Diar } \\
\text { Yo casos }\end{array}$ & $\begin{array}{l}\text { a A } \\
r e a^{\prime \prime} \\
\% \quad A\end{array}$ & $\begin{array}{r}\text { Grup } \\
\text { "S } \\
N o \text { cas }\end{array}$ & $\begin{array}{l}o B \\
\text { nos" } \\
\text { is } \%\end{array}$ & $\begin{array}{r}G r \\
{ }^{\prime C} \mathrm{Co} \\
\mathrm{dia} \\
N^{o} \mathrm{ca}\end{array}$ & $\begin{array}{l}\text { upo C } \\
\text { tacto } \\
\text { rrea" } \\
\text { sos \% }\end{array}$ \\
\hline Sin agente infeccioso & o 38 & 43,2 & 27 & 54,0 & 8 & 20,0 \\
\hline Sólo virus & 10 & 11,3 & 3 & 6,0 & 1 & 2,5 \\
\hline Sólo bacterias * & 11 & 12,5 & 6 & 12,0 & 4 & 10,0 \\
\hline Sólo parásitos ** & 13 & 14,7 & 9 & 18,0 & 18 & 45,0 \\
\hline $\begin{array}{l}\text { Con mezcla de } \\
\text { agentes infecciosos }\end{array}$ & 16 & 18,3 & 5 & 10,0 & 9 & 22,5 \\
\hline TOTAL & 88 & 100,0 & 50 & 100,0 & 40 & 100,0 \\
\hline
\end{tabular}

- Escherichia coli enteropatógenas, Shigellas, Salmonellas. E1 estudio bacteriológico del coprocultivo se realizó en el Ins- El estudio parasitologico fue hecho por la Unidad de Parade Medicina, Sede Santiago Norte, Universidad de Chile. 
T A B L A 3

DISTRIBUCION POR EDAD Y AISLAMIENTO DE VIRUS. NIÑOS CON DIARREA (A), CONTROLES SANOS (B) Y CONTACTOS DE DIARREA (C)

\begin{tabular}{|c|c|c|c|c|c|c|c|c|c|}
\hline \multirow{3}{*}{ Edad } & \multirow{3}{*}{$\begin{array}{l}\text { Grup } \\
\text { Casos } \\
N^{o}\end{array}$} & \multirow{2}{*}{\multicolumn{2}{|c|}{$\begin{array}{c}A \text { "D'arrea" } \\
\text { Aislamiento }\end{array}$}} & \multirow{2}{*}{\multicolumn{3}{|c|}{$\begin{array}{cc}\text { Grupo } & \text { B "Sanos" } \\
\text { Casos } & \text { Aislamiento }\end{array}$}} & \multirow{3}{*}{$\begin{array}{c}\text { Grupo } C \\
\text { Casos } \\
N^{\varphi}\end{array}$} & \multirow{2}{*}{\multicolumn{2}{|c|}{$\begin{array}{l}\text { "Contactos Diarrea" } \\
\text { Aislamiento }\end{array}$}} \\
\hline & & & & & & & & & \\
\hline & & $N^{o}$ & $\%$ & $N^{o}$ & $N^{o}$ & $\%$ & & $N^{o}$ & $\%$ \\
\hline 6 meses o menos & 30 & 5 & 16,6 & 16 & 3 & 18,7 & 3 & 0 & - \\
\hline 6 meses 1 día -1 año & 20 & 5 & 25,0 & 10 & 1 & 10,0 & 1 & 0 & - \\
\hline 1 año 1 día -2 años & 23 & 6 & 26,0 & 14 & 3 & 21,4 & 1 & 1 & - \\
\hline 2 años 1 día -6 años & 15 & 4 & 26,8 & 10 & 1 & 10,0 & 35 & 7 & 20,0 \\
\hline TOTAL & 88 & 20 & 22,9 & 50 & 8 & 16,0 & 40 & 8 & 20,0 \\
\hline
\end{tabular}

T A B L A 4

TJPOS DE VIRUS AISLADOS DE DEPOSICIONES EN NINOS CON DIARREA (A), CONTROLES SANOS (B) Y CONTACTOS DE DIARREA (C)

\begin{tabular}{lrrr}
\hline Virus (tipos) & \multicolumn{4}{c}{$\begin{array}{c}\text { Número de tipos de virus aislados } \\
\text { Grupo }\end{array}$} & Grupo & B & Grupo $C$ \\
\hline ECHO $(6,7,11$ y 19) & 6 & 1 & 3 \\
Coxsackie A & 3 & 2 & 0 \\
Coxsackie B $\left(\begin{array}{lll}3 & \text { y } & 5\end{array}\right)$ & 3 & 2 & 4 \\
Viruspolio (2) & 2 & 0 & 0 \\
Herpes simplex & 2 & 0 & 0 \\
Virus "no tipificable" & 6 & 3 & 1 \\
\hline Total & 22 & $\mathbf{8}$ & $\mathbf{8}$ \\
\hline
\end{tabular}

* Se aisló dos virus ECHO tipo 6 en el Grupo A y dos en el Grupo C.

en los controles sanos. En los menores de dos años sólo son comparables los grupos A y B, dado el reducido número de casos de esa e:ład del grupo C. En esa edad resalta el hecho que el porcentaje de aislamiento de virus en las deposiciones del grupo "diarrea" es francamente mayor en los lactantes de seis meses a un año que en los controles de esa edad $(25 \%$ y $10 \%$ respectivamente). El estudio de los mayores de dos años revela que en los grupos "diarrea" y "contactos" los porcentajes de aislamiento viral son más altos que en los grupos "sano": $27 \%$ y $20 \%$ versus $10 \%$.

En la Tabla 4 se muestra el análisis de los tipos de virus aislados. Se observa que no hay adenovirus; las características del efecto citopático de los cultivos celulares inoculados descartaban a estos virus. De los 20 coprocultivos positivos, dos presentaban simultáneamente dos tipos de virus, dando un total de 22 tipos. Dos niños que tienen viruspolio tipo 2 en sus deposiciones, habían recibido vacunación oral Sabin 60-70 días antes de la toma de la muestra. Otros coprocultivos presentan virus Herpes Simplex. Nos quedan 18 tipos de virus. Entre éstos destacan por su frecuencia de aislamiento los virus FCHO: 6 de un total de 18 niños con diarrea (grupo A), contra uno de 8 en los sanos (grupo B) y 3 de 8 en los contactos (grupo C). Los otros tipos de virus aislados: Coxsackie A, Cosackie B y virus "no tipificable", se aislan indistintamente en los tres grupos de niños, en mayor proporción en los niños sanos. Como puede verse en la Tabla 5 el grupo de niños con diarrea muestra un buen desarrollo de anticuerpos neutralizantes contra los virus aislados, incluso en algunos casos ya en la muestra de fase aguda.

$\mathrm{El}$ virus ECHO tipo 6 se aisla con mayor frecuencia, tanto en los niños con diarrea como en los contactos. Por ello se estudió el título de anticuerpos neutralizantes contra este virus en todos

TABLA 5

RELACION ENTRE AISLAMIENTO VIRAL Y DESARROLLO DE ANTICUERPOS SERICOS NEUTRALIZANTES ESPECIFICOS EN NINOS CON DIARREA

\begin{tabular}{|c|c|c|c|c|}
\hline \multirow[b]{2}{*}{ Caso } & \multirow[b]{2}{*}{ Edad } & \multirow[b]{2}{*}{$\begin{array}{l}\text { Virus aislado } \\
\text { en deposiciones }\end{array}$} & \multicolumn{2}{|c|}{$\begin{array}{c}\text { Anticuerpos } \\
\text { neutralizantes especif. }\end{array}$} \\
\hline & & & $\begin{array}{l}\text { Fase } \quad \text { Fas } \\
\text { Aguda Conv }\end{array}$ & aleciente \\
\hline D.N.A. & 4 meses & Viruspolio 2 & $1 / 256$ & $1 / 256$ \\
\hline E.G.L, & 4 meses & ECHO 11 & $1 / 64$ & $1 / 64$ \\
\hline J.M.F. & 8 meses & No tipificable & $1 / 4$ & $1 / 4$ \\
\hline G.T.R. & 11 meses & No tipificable & $-1 / 4$ & $+*$ \\
\hline A.P.V. & 1 año & ECHO 6 & $1 / 64$ & $1 / 64$ \\
\hline J.S.O. & 1 aก̃o & ECHO 6 & $1 / 1024$ & $1 / 1024$ \\
\hline L.P.C. & 2 años & No tipificable & $<1 / 4$ & $1 / 16$ \\
\hline P.S.C. & 4 años & Coxsackie $B_{3}$ & $1 / 4$ & $1 / 64$ \\
\hline C.E.O. & 5 años & Coxsackie $B_{5}$ & $<1 / 4$ & $1 / 4$ \\
\hline
\end{tabular}

* El suero, fase convaleciente, fue insuficiente para hacer la titulación. 
T A B L A 6

ANTICUERPOS NEUTRALIZANTES ESPECIFICOS CONTRA VIRUS ECHO 6 Y COXSACKIE $B_{3}$, EN NINOOS CON DIARREA, DISTRIBUIDOS $S E G U N$ EDAD

\begin{tabular}{lrrrrrr}
\hline \multirow{2}{*}{ Edad } & \multicolumn{5}{c}{ Seropositividad $a^{*}$} \\
& & $N^{o}$ & \multicolumn{1}{c}{$\%$} & \multicolumn{1}{c}{$N^{o}$} & $\%$ \\
\hline 6 meses o menos & 21 & 2 & 9,5 & 1 & 4,8 \\
6 meses 1 día - 1 año & 14 & 5 & 35,7 & 2 & 14,2 \\
1 año 1 día - 2 años & 16 & 3 & 18,7 & 3 & 18,7 \\
2 años 1 día - 6 años & 9 & 3 & 33,3 & 1 & 11,1 \\
\hline Total & 60 & 13 & 21,6 & 7 & 11,6 \\
\hline
\end{tabular}

- Se consider 6 seropositivos los sueros que presentan: a) seroconversión, b) alza del título de anticuerpos de 4 veces o más y c) los que tienen tıtulo de anticuerpos de 1/64 o más.

los sueros pareados de los niños con diarrea. Como control se determinó en los mismos sueros los anticuerpos presentes contra virus Coxsackie $B_{3}$, virus que se aisla indistintamente en los tres grupos de niños. En los grupos B y C no se pudo hacer un estudio semejante por las dificultades para obtener muestras de sangre de niños sanos. Se dispuso de 60 muestras pareadas, fase aguda y convaleciente, del total de 88 niños del grupo A. Los resultados de seropositividad y su relación con la edad se muestran en la Tabla 6. La positividad de la serología para ambos virus es baja antes de los seis meses de edad, experimentando una fuerte alza al alcanzar el segundo semestre de vida. Comparando las respuestas de anticuerpos específicos contra ambos virus se observa que en todas las edades, a excepción del grupo 1-2 años, el número de niños con anticuerpos contra ECHO 6, duplica a los con anticuerpos contra Coxsackie $B_{3}$. Esta diferencia de porcentajes es aún mayor en los lactantes entre 6 meses - un año: $36 \%$ con anticuerpos para virus ECHO 6 y $14 \%$ con anticuerpos para virus Coxsackie $\mathbf{B}_{3}$.

Discusion. En el presente trabajo, se observa que durante la crisis diarreica, un $57 \%$ de los niños presenta agentes infecciosos en sus deposiciones, ya sea virus, bacterias enteropatógenas, enteroparásitos o una mezcla de ellos, resultado similar al observado por otros autores tanto en Chile $^{2}$, como en EE.UU. y Europa Occidental ${ }^{3}$. Es probable que este porcentaje aumente significativamente cuando se logre detectar en forma rutinaria otros virus pequeños, como el llamado "virus de la diarrea" 9 .

El porcentaje de niños con diarrea que tiene virus, como único agente infeccioso en el co- procultivo, es casi el doble al observado en los niños sanos, fenómeno que no se observa al analizar la prevalencia de bacterias enteropatógenas, ni enteroparásitos. También es mayor el número de niños con diarrea en los cuales se detecta más de un tipo de agente infeccioso y de éstos el $62 \%$ tiene virus. Curiosamente, un gran número de ninos sanos tiene agentes infecciosos en sus deposiciones, pero entre ellos predominan parásitos y bacterias. Los contactos de los niños con diarrea se destacan por estar altamente contaminados; así un $45 \%$ presenta enteroparasitosis y otro $33 \%$ tiene bacterias o mezcla de agentes infecciosos. Sin embargo, este grupo debe ser considerado aparte, dado que el $90 \%$ de los niños contactos tienen más de dos años de edad, lo que impide su comparación con los niños con diarrea y sus controles.

Los porcentajes de aislamiento viral obtenidos en el presente trabajo, $23 \%$ para los niños con diarrea y $16 \%$ para los controles, son más altos que los observados durante dos veranos consecutivos en el Area Occidente de Santiago ${ }^{6}$. Tomando ambos períodos en conjunto, Wu y cols. ${ }^{6}$ encontraron tasas de aislamiento viral del $13 \%$ para los lactantes con diarrea y $15 \%$ para los sanos $^{6}$. Las diferencias encontradas pueden atribuirse en parte al mayor rango de huésped utilizado ya que esta vez se trabajó en dos líneas de células y en un cultivo primario. Este último es muy sensible a enterovirus, permitiendo detectar algunos tipos de virus ECHO que no pueden aislarse en líneas celulares. Además, se analizó un porcentaje significativo de muestras en ratones recién nacidos, huésped adecuado para los virus del grupo Coxsackie A. En este trabajo la mayor diferencia de aislamiento viral entre los niños con diarrea y los controles se observó entre los 6 y 12 meses de vida, mientras que en 1966-68 la mayor tasa de aislamiento se obtuvo en los lactantes pequeños ${ }^{6}$. El desplazamiento viral hacia lactantes mayores parece deberse a la implantación de la va. cunación oral del recién nacido con viruspolio tipo 1, a contar del año 1971. Esta vacunación con virus vivo probablemente interfiera con el prendimiento de otros enterovirus en los primeros meses de vida ${ }^{10}$.

Algunos virus aislados en el coprocultivo del grupo diarrea pueden descartarse, a priori, como agentes etiológicos específicos. Entre ellos tenemos dos casos, con antecedentes de vacunación Sabin relativamente reciente, en los que se aisló viruspolio, tipo 2, probablemente de origen vaccinal. También parece razonable descartar el virus Herpes simplex, aislado en otros dos casos, por su muy dudosa participación en las diarreas. Con excepción del grupo de virus ECHO, cuyo papel como agente etiológico de las diarreas infantiles ha sido analizado recientemente ${ }^{10}$, los otros vi- 
rus: Coxsackie A, B y virus "no tipificable", se aislan por igual en los tres grupos de niños estudiados, destacándose por su ubicuidad los virus Coxsackie $B_{3}$. Sólo los virus ECHO se encuentran en proporción francamente mayor en el coprocultivo de los niños con diarrea que en los controles, y de ellos el más importante parece ser el virus ECHO 6. En contraste con el último trabajo realizado en Santiago, el virus ECHO 20 no parece jugar esta vez ningún papel etiológico ${ }^{6}$. Recordaremos que todo ese estudio se centró en un ârea de Santiago, encontrándose predominancia de virus ECHO 20 sólo en uno de los veranos analizados. Esta vez se procedió a tomar muestras en forma sucesiva en diferentes sectores de Santiago, con lo que se introducen cambios en dos parámetros simultáneamente: localidad geográfica y período estival. Al considerar estos factores, se vio que casi todos los casos de aislamiento de virus ECHO 6 se hicieron en los dos primeros consultorios analizados, durante el mes de enero, hecho que apunta a características ecológicas propias de los virus considerados agentes etiológicos de diarrea infantil ${ }^{10}$.

El estudio del título de anticuerpos séricos para los virus aislados en el coprocultivo indica una buena correlación entre ambos. Utilizando el título de anticuerpos contra virus Coxsackie $B_{3}$ como patrón de comparación encontramos que un $36 \%$ de los lactantes con diarrea, entre los seis y doce meses de vida, posee anticuerpos contra virus ECHO 6, mientras que sólo un $14 \%$ de los lactantes de esa edad posee anticuerpos contra virus Coxsackie $\mathrm{B}_{3}$. Recordaremos que los lactantes de esa edad presentan mayor diferencia de aislamiento viral entre los grupos "diarrea" y "control". Nuevamente los casos seropositivos para virus ECHO 6 se concentran en los dos primeros consultorios estudiados. Aun cuando los casos de aislamiento de virus ECHO 6 sean pocos, el hecho de encontrar buenas tasas de anticuerpos contra este virus en un alto porcentaje de lactantes señala una vez más la posible implicancia del virus ECHO 6 como agente etiológico de algunas diarreas infantiles.

\section{RESUMEN}

Se estudió la etiología viral de algunas diarreas infantiles en el verano de 1973 en Santiago. Se hizo coprocultivo de 88 niños con diarrea (Grupo A), de 50 niños controles sanos (Grupo $B$ ) y de 40 niños contactos de los enfermos (Grupo $C$ ). Se titulo anticuerpos séricos del Grupo A en muestras pareadas. Alrededor del $80 \%$ de los niños era menor de dos años en los Grupos $A$ y B, mientras que un $90 \%$ de los niños era mayor de 2 años en el Grupo C. La tasa de aislamiento viral fue de $23 \%$ para los niños con diarrea, $16 \%$ para los controles y $20 \%$ para los contactos. En los lactantes de 6 meses a un año de edad, se obtuvo tasas de aislamiento de $35 \%$ para el Grupo $A$ y $10 \%$ para el Grupo B. El análisis de los virus aislados en el coprocultivo señaló predominancia de virus $\mathrm{ECHO}$ (tipos 6, 7, 11 y 19) en los niños con diarrea, especialmente ECHO tipo 6. Otros virus aislados fueron: Coxsackie $B$ (tipos 3 y 5), Coxsackie A y virus "no tipificable", pero éstos se distribuyen en forma equivalente $e_{n}$ los tres grupos estudiados, destacándose por su ubicuidad el virus Coxsackie Bs. Los niños con diarrea desarrollaron anticuerpos séricos para el virus tipo aislado de su coprocultivo. Los titulos de anticuerpos contra virus ECHO 6 y Coxsackie $B_{3}$ se midieron en 60 sueros pareados del Grupo A, encontrándose que el $11 \%$ de los niños poseía anticuerpos contra Coxsackie $B_{3}$, y $22 \%$ rontra ECHO 6. La diferencia más notable se observó en los lactantes de seis meses a un año de edad, ya que mientras un $14 \%$ tenía anticuerpos para virus Coxsackie $B_{3}$, un $36 \%$ poseía anticuerpos para virus ECHO 6.

\section{SUMMARY}

The viral etiology of some infantile diarrhea was studied during Summer, 1973 in Santiago. Stool cultures were made in 88 children with diarrhea (group A), 50 healthy children (group B) and 40 contacts of the sick children (group C). Serum antibodies in paired samples were measured in group A. About $80 \%$ of children were below 2 years old in groups $A$ and B, while $90 \%$ of them, were over 2 years in group C. The porcentage of viral isolation was $23 \%$ for children with diarrhea, $16 \%$ for the controls and $20 \%$ for the contacts. In the infants aged 6 months - 1 year, these percentages were $35 \%$ for group A, and $10 \%$ for group B. The analysis of all viruses isolated in the stool cultures showed predominance of ECHO viruses (types $6,7,11$ and 19) in the children with diarrhea, specially ECHO 6 virus. Other virus isolated were: Coxsackie B (types 3 and 5), Coxsackie $A$ and "non typifiable" virus, but these were distributed equally in the three groups of children studied, being Coxsackie $B_{\sharp}$ virus the most ubiquous of them all. The children with diarrhea attained adequate levels of antibodies for the virus type isolated in their stool cultures. The title of serum antibodies for ECHO 6 and Coxsackie $\mathrm{B}_{3}$ virus were measured, in 60 paired sera of group $A$, thus finding that $11 \%$ of the children had antibodies against Coxsackie $\mathrm{B}_{3}$ and $22 \%$ against ECHO 6 . The greatest difference was observed in the infants, aged 6 months 1 year old, since $14 \%$ had antibodies against Coxsackie $\mathrm{B}_{3}$ while $36 \%$ of them had antibodies against ECHO 6 virus. 


\section{REFERENCIAS}

1.-Anuario 1971. Defunciones y Causas de Muerte, Servicio Nacional de Salud, Subdepartamento Estadística (Julio 1972).

2.-Lobos, H., Aguilar, C. y Romero, H. Bacteriología de las diarreas agudas en el lactante hospitalizado. Pediatría 8: 280-293, 1965.

3.- Cramblett, H. C. y Siewers, C.M.F. The etiology of gastroenteritis in infants and children, with emphasis on the occurrence of simultaneous mixed viral-bacterial infections. Pediatrics 35: 885-898, 1965.

4.-Parks, W.P., Melnick, J.L., Queiroga, L.T. y Ali Khan, $\boldsymbol{H}$. Studies of infantile diarrhea in Karachi, Pakistan. I Collection. Virus isolation and typing of viruses. Amer. Journal of Epidemiology 84: 382-394, 1966.

5.-Ramos Alvarez, M. y Olarte, J. Diarrheal diseases of children. Amer. Journal Dis. Child. 107: 218 231, 1964.
6.-Wu, E., Contreras, G., Ohlbaum, A., González, C. y Gilabert, B. Estudio sobre la etiología viral de las diarreas agudas del lactante e influencia de la vacunación Sabin sobre la flora de enterovirus. Revista Chilena de Pediatría 42: 225-238, 1971.

7.--Schmidt, N.J. y Lennette, E.H. Basic Technics for Virology in "Viral and Rickettsial Infections of Man”. Edited by Horsfall F.L. and Tamm J. 4th. Ed. J.B. Lippincott Co., Philadelphia, Toronto.

8.-Lim, K.A. y Benyesch-Melnick, M. Typing of viruses by combinations of antiserum pools: application to typing of enterovirus (Coxsackie and ECHO). J. Immunol. 84: 309-317, 1960.

9.-Kapikian, A.Z., Wyatt, R.G., Dolin, R., Thornhill, T.S., Kalica, A.R. y Chanock, R. Visualization by immune electron microscopy of a $27 \mathrm{~nm}$ particle associated with acute infectious nonbacterial gastroenteritis. J. of Virology 10: 1075, 1972.

10.-Contreras, $G$. Sabin's vaccine used for nonspecific prevention of infant diarrhea of viral etiology. Pan American Health Organization 8: 123-132, 1974. 